\title{
REBORN TRANSLATED
}

\author{
Xiaolu Guo as a World Author
}

\author{
Flair Donglai Shi \\ University of Oxford \\ donglai.shi@warwick.ac.uk / donglai.shi@queens.ox.ac.uk
}

\begin{abstract}
This paper introduces the concept of "world author," taking as its exemplar the Chinese British writer and filmmaker Xiaolu Guo. It investigates how Guo utilizes her bilingualism to construct and negotiate her creative agency, especially when dealing with the political and commercial forces imposed on diasporic authors. Through engaging with Rebecca Walkowitz's idea of world literature as being "born translated," I point out that the translational should not be limited to the thematic and representational arrangements internal to a given text. Instead, translation as movements between linguistic systems and media forms can generate multiple versions of a text, to the point that such translational multiplicity fundamentally challenges its supposed singularity. This argument is demonstrated with Guo's self-translation of the stories of Fenfang and her filmic adaptation of the novel UFO in Her Eyes. Through these examples of what I call "translational rebirths," I demonstrate the importance of paratextual details and intertextual connections between clusters of an author's creative output for the interpretation and appreciation of l'ouvre d'un auteur instead of une ceuvre d'art. This case study also shows the need for the academic debates on world literature to go beyond the singularity of texts and evaluative criteria of worldliness based on this assumption, so that the discipline can realize its full potential in accommodating multilingual transnational authors like Guo.
\end{abstract}

\section{Keywords}

World Literature, Xiaolu Guo, Bilingualism, Minor Literature, Translational 


\section{About the Author}

Flair Donglai Shi (施東來) is a final year PhD student at the University of Oxford and works at Warwick University as Associate Tutor in Translation and Cultures. His doctoral project investigates the racist concept of "the Yellow Peril" as a traveling discourse in contexts as diverse as early 2oth century England, Apartheid South Africa, and post-Mao China and posthandover Hong Kong. His articles have appeared in Comparative Critical Studies, Women: A Cultural Review, Chinese Literature: Essays, Articles, Reviews, and Comparative Literature $\mathcal{E}$ World Literature. His edited volume, World Literature in Motion: Institution, Recognition, Location (2020), is published and distributed by ibidem in Europe and Columbia University Press in the US. His other research interests include Alice in Wonderland and China, theories of World Literature, modern Chinese and Taiwanese literature in translation, as well as ChinaAfrica relations in the cultural domain. 
Art is beyond realism. Art is beyond geographical time and space. Art is obviously beyond dissidence. That should be our motto when we are trying to discover a powerful authentic form of art. The only moralistic concern in the artistic world perhaps is this: do we care more about the art produced by the artist, or the artist [sic] themselves? A humanist question.

—Xiaolu Guo, "Beyond Dissidence"

Xiaolu Guo made the above statement in a commentary for the British newspaper The Independent in late 2012. It was published soon after the Swedish Academy announced that the Nobel Prize in Literature for that year was to be awarded to the Chinese writer Mo Yan, a prominent figure in China who had always worked with and received official endorsements from the country's cultural establishment led by the Chinese Communist Party (CCP). Dissatisfied with the condemnation that many dissident Chinese writers and the western media in general directed towards this nomination, Guo opined that these criticisms were "misguided to presume that in a totalitarian society it's a choice between artistic suicide or the personal suicide of political martyrdom" (Guo 2012). Citing Yan Lianke as another example, Guo argues that Chinese writers do not have to be devoted political dissidents and can instead carve out creative spaces that accommodate their artistic ambitions and social concerns in subtle and sophisticated ways. In other words, Guo answers the "humanist question" she raises by pointing out the false binary between state and art. It is also her belief that Chinese writers, based either in China or overseas, should not be reduced to native informants for the West, or political spokespersons for China.

However, this awareness of the prevalent forces of political reductionism in popular discussions of Chinese cultural production does not completely free Xiaolu Guo herself from their imposition. The drastic change made to the title of her commentary serves as a good example of this. On Guo's personal website, it can be observed that the original title she had for this piece was a rather simple and straightforward phrase "Beyond Dissidence," whereas in the version published in The Independent, it was replaced by a rather lengthy sentence, added with much extra political flavor: "Great art behind an iron curtain: Are all Chinese novelists 'state writers"' (Guo 2013). Not only is the term "iron curtain" deliberately evocative of cold-war sensibilities that have always fed on the image of China as the Oriental despot, the rather universalistic intellectual reflections Guo expresses in the piece have also been framed as a particular issue troubling "all Chinese novelists." Indeed, it is likely that The Independent asked Guo to write this commentary because she is the most prominent bilingual novelist of Chinese descent based in the UK. In the 
eyes of many western media and readers, she naturally becomes a spokesperson for China and its highly politicized cultural realm.

Born in 1973, Xiaolu Guo grew up with her grandparents in a small fishing village named Shitang in China's southern province Zhejiang. Before she received a Chevening Scholarship from the British government to study film in England in 2002, she had already been establishing herself in Beijing as a novelist, scriptwriter, and film critic. Notably, unlike the earlier generation of exiled Chinese writers who left mainland China in the wake of the June Fourth Incident in 1989 and were more or less unable to return to the country for a long time, Guo's relocation to the West was a voluntary act of career advancement and personal development. As she records in her memoir, soon after she arrived in London, she "realized there had been some truth to my [her] own country's Communist education: The West was not milk and honey" (Guo 2017, 246). Nevertheless, she devoted much time to bettering her English skills and successfully adapted herself to working in a more international environment. After finishing her studies, she also went to live in Paris and Berlin for some years before eventually settling down in London again.

These experiences in Europe have enabled Guo to remake herself as a transnational and bilingual cultural worker actively producing artistic content in a range of genres and forms. As an Anglophone writer, she has been equally critical of both political and commercial (self-)censorship, thereby refusing to single out China as "the despotic Oriental Other" vis-à-vis the "free" West. As she says, "self-censorship happens not only in China ... I'm always saying that commercial censorship is our foremost censorship globally today. Why do we still pretend we are free?" (Guo 2014a) This statement reveals Guo's sensitivity towards "the dialectic struggle between international mobility and intranational accessibility" for contemporary Chinese writers in the world (Shi 2016, 20).

Indeed, unlike many other bilingual Chinese writers who prioritize international mobility and actively disengage the mainland Chinese literary market with their "banned in China" works, Xiaolu Guo has always demonstrated a high degree of willingness to secure her unique presence both in China and abroad. ${ }^{1}$ This strong willingness is most clear in her continued participation in two types of transnational cultural activities: literary translation and multilingual filmmaking.

First, translation, both in the narrow sense of linguistic movement and in the broader sense of intercultural exchange, has been central to her literary practices since the early 20oos. Extant scholarship on Guo has highlighted the persistent themes of feminist Bildungsroman and intercultural (mis-)understanding in her works, and literary critics have noted the innovative ways in which she employs formalistic features of code-switching and multimedia bricolage on the page. 
However, the overwhelming majority of academic studies on Guo focuses on her most well-known novel A Concise Chinese-English Dictionary for Lovers (2007), which is made up of a series of dictionary-like diary entries written mainly in broken English (Gilmore, Oboe, Spira, Wangtaolue Guo, Poon, Kong, Hwang, Dervin and Gao, and Doloughan 2018). Rarely have scholars noticed that Guo first made herself known to Anglophone readers via the English translation of the second novel she wrote in Chinese, Woxinzhong de Shitouzhen (2003), or Village of Stone (2004). Translated by Cindy Carter, this semi-autobiographical novel about Guo's childhood in Shitang was first published in the UK by Chatto \& Windus. It was shortlisted by Independent Foreign Fiction Prize in 2005, and Chatto \& Windus has since then been Guo's most loyal literary partner, with whom she published all of her subsequent works in English. Hence, it is fair to say that Guo's international literary career began in translation, a mode of multilingual creativity that involves active transnational engagement. Nowhere is this engagement clearer and more interesting than the Chinese translations of her most discussed work, $A$ Concise Chinese-English Dictionary for Lovers, which constitute the translingual afterlives of this novel rarely mentioned in the numerous papers focusing on close readings of the (broken) English original. Because the novel is a highly stylized record of a Chinese girl's English acquisition both in terms of its formalistic arrangements (the gradual improvement in English grammar and syntactic sophistication) and its thematic concerns (cultural shock and sexual awakening), Guo's first reaction to the idea that it could be translated into Chinese was that it would be "an absurdity" (Xiaolu Guo qtd. in Wangtaolue Guo 111). Should the book's broken English be translated into grammatically incorrect Chinese? And how does one capture the protagonist's many comments on the eccentricities of the English language in Chinese? Whether the translators can succeed at these tasks is a topic that warrants another thorough scholarly investigation (I address this very topic through a comparative analysis of the two existing Chinese-language translations of this novel in Shi 2021). The important fact is that these technical difficulties regarding the untranslatability of the novel did not scare away her Chinese-language publishers. A Taiwanese translation by Guo Pingjie soon appeared in 2008, followed by a simplified Chinese version published in mainland China in 2009, translated by Miu Ying. As this case indicates, Guo's moving overseas did not confine her to a monolingual Anglophone sphere; instead, this distance has helped her expand her readership in the Chinesespeaking world as well.

Second, the professional identity of a multilingual filmmaker is equally important for Xiaolu Guo, and its cultivation and maintenance has always demanded her to work across national boundaries, involving collaboration with a diverse range of crew members, producers, and audiences from China and Europe. Although she studied and taught film for many years at the Beijing Film Academy (she was classmates with the prominent Chinese director Jia Zhangke at one point), it was 
after she came to Europe in 2002 that she started writing and directing her own feature films and documentaries. From her first video essay, Far and Near (2003), to her latest documentary feature, Five Men and a Caravaggio (2018), most of Guo's visual works address the contemporary situation of China and Chinese migrants. Heavily influenced by La Nouvelle Vague of the 196os, Guo often employs arthouse filmmaking techniques such as narrative fragmentation, hand-held camera movement, and extreme close-ups to present her realist concerns about subaltern groups, especially women in rural China. More importantly, Guo as a filmmaker is manifestly more anti-commercial than Guo as a novelist. Funded by a variety of European cultural institutions, she has had to write scripts and direct films with limited budgets. None of her feature films have been widely released in cinemas anywhere, but they were often selected by international film festivals and screened at regional cultural events. Despite, or perhaps owing to, their limited circulation, most of Guo's visual works are available for purchase and download online, both in China and abroad. Guo's ability to maintain her detached position in both contexts makes her stand out among transnational filmmakers who primarily strive for commercial success in the age of global capitalism. However, except for some scattered discussion on Guo's 2009 narrative film, She, A Chinese, which is a story of rural-urban as well as East-West migrancy similar to A Concise Chinese-English Dictionary for Lovers, literary critics and film scholars have largely neglected her other visual works and the complex entanglements they have with Guo's literary practices (Doloughan 2015).

This paper addresses the lack of scholarship on Xiaolu Guo's multifaceted artistic output and proposes a more holistic approach to studying the mechanisms and themes of translation that have been key to her transnational and multilingual creative career. The following sections, "Translational Boomerang" and "Translational Visuality, examine two different sets of creative works in Guo's textual and visual oeuvre, with particular attention to their respective processes of translingual adaptation. The term "translational" as employed in this paper refers to movements between different linguistic and media systems, with a particular focus on cases in which the very creative contents of texts are generated by and located in such translingual and trans-media movements. Engaging with Rebecca Walkowitz's theories regarding the "born translated" features of contemporary world literature, I contend that Guo's artistic practices have gone beyond simply producing singular texts with translational features to be consumed by Anglophone readers with global tastes. Her status as a world author is achieved through a strong willingness and devoted efforts to produce multilingual content in multiple formats and spheres of cultural circulation, and I call this process "reborn translated" so as to highlight the multi-directional routes taken by the acts of translation in her creative universe. This paper concludes with a short polemic section elaborating on the necessity of the concept "world author" vis-à-vis "minor literature" and "world literature." 
One blind spot in the current debate on world literature is that most scholars have been too focused on the question of whether a particular work qualifies as or displays certain said features of world literature and thus fail to note the existence and importance of multiple versions of texts mediated by intertextuality and translation, which essentially dispute the idea that a singular text can exist in the first place. Bringing in the concept of "world author" does not mean a retrogression to the conventional mode of biographical study, nor does it in any fundamental way deny the value of a flourishing academic discourse like world literature. On the contrary, this polemic section concludes the paper with three reasons as to why world literature serves as the most pragmatic and beneficial disciplinary space for transnational bilingual authors like Xiaolu Guo.

\section{TRANSLATIONAL BOOMERANG: FENFANG'S STORY, 2000, 2008, AND 2010}

As mentioned above, Village of Stone was Guo's first novel to be translated into English, but it was actually her second novel published in Chinese, written around the time she went to England to study. Her debut novel in Chinese, Fenfang de Sanshiqiduer (Fenfang's 37.2 Degrees), is a much longer piece of contemporary fiction published in 2000. Fenfang, the eponymous protagonist of the novel, is a young girl striving to become an actress and scriptwriter in China's capital city Beijing. The stories in the book are narrated by Fenfang through the first-person point of view, creating a diary-like style of intimate confession. Occasionally addressing the reader as "you," Fenfang confides to us the difficulties she encounters in her professional life as well as the emotional struggles she has been through with her violent Chinese ex-boyfriend, Mumu, and her American boyfriend, Michael.

Guo's interest in formalistic experiments can already be observed in this early text. Firstly, apart from its diary-like style, the novel has an interesting layout: it is divided into eight chapters, each of which has a single Chinese character as its title, and these eight characters-duo (哆), lai (唻), mi (咪), fa (发), suo (索), la (拉), ti (梯), duo ( 哆)-correspond to the eight basic musical notes (C、D、E、F、G、A、B、C\#) bringing the beginning and the end to a full circle. This series of musical notes also represents an escalation of Fenfang's mood swings as she anxiously waits for Michael to return from America. The higher-pitch $d u o$ of the last chapter marks the novel's anti-climactic ending, where Fenfang relays to the reader that Michael has simply disappeared after a reported plane accident.

Secondly, even though she was not yet fully bilingual when she wrote this novel and the book was mostly read by monolingual Chinese readers, Guo has inserted many English words in Fenfang's narration. These English words flow naturally 
from Fenfang's thoughts and speeches and most of them are the names of popular Western musicians she listens to, such as "Wasted," "Cassandra Wilsond [sic]," "U2," "Pink Floyd," and "The Beatles" (Guo 2000, 74), and the imported goods she and Michael used to share in their daily life, such as "Butler Flossmate" (dental floss brand), "One a Day" (Vitamin capsule brand), and "All in your Head" (shampoo brand) (251). The final chapter also contains the original email Michael had sent to Fenfang before he boarded the plane, which is written in English with an E.E. Cummings poem attached to it (247). Rather than making the novel less Chinese, such occasional insertions of English usages in the text lend much authenticity to its representation of the lifestyle of a new generation of Chinese urban dwellers. Born in the 1970s, Xiaolu Guo and Fenfang belong to the first post-Cultural Revolution generation who have experienced their early adulthood in the full swing of the nation's reform and open-up policy. Consumption of Western culture and goods was fashionable in the 1990s, and international romance also became more common as China welcomed foreign visitors. In this sense, Fenfang de Sanshiqiduer shares with Guo's later works many translational features and thematic concerns of intercultural communication.

Lastly, Guo adopts the modernist technique of stream of consciousness to present Fenfang's inner thoughts. This involves large chunks of Chinese sentences presented without any punctuation, and when these paragraphs appear, the density of the Chinese characters on the page generates disorienting effects, both visually and semantically. This way of writing is against the convention of modern Chinese literature, and it is disorienting because unlike the compulsory use of spaces to separate words in English writing, there are no spaces between Chinese characters that make up different words, and thus Chinese sentences rely heavily on punctuation for comprehensibility. For example, in the second chapter "lai," Fenfang is brought to the police station during the investigation of a murder case in her block. Unaware of what happened, Fenfang starts to wonder what crimes she could have committed in her lifetime, but her anxiety only produces quick flashbacks of a series of insignificant errors: 


\section{从黄昏到晚上十点了。没有警察过来审问我们。我开始} 反省我短短一生做过的错事，可是实在没有什么值得一提的 伟大的错事。

我中学一次考试时曾经想打小抄可最终没敢拿出我事先 准备的书本我在电影院里工作时拾到过一个白金戒指我自己 留了起来我也捡了本英文字典我自己收了起来化令污为动力 好好学习天天向上了我还拾到个大耿大我送给了我们电影公 司的副经理但说实话其实从来没有一个观众回电影院来找这 些东西对了我还谈过几个男朋友但从来没有破坏军婚也没有 插足做第三者也没有泼人硫酸尽管我自己差点被木木弄死这 是我自己的事没有影响他人此外我这辈子还做过什么坏事 呢?

[From dusk to 10 o'clock in the evening. No police came to interrogate us. I started to reflect on the mistakes I made in my short life, but none of them are really worth mentioning.

During an exam in middle school I thought about cheating but never dared to take out the book I prepared beforehand when I was working in the cinema I picked up a platinum ring and kept it I also picked up an English dictionary and kept it to myself turning corruption into motivation study well and make progress every day I also picked up a mobile phone and gifted it to the deputy manager of our cinema company but to be frank no one ever comes back to the cinema to look for these things oh yes I even had several boyfriends but never did I get involved with a married military man nor did I become a mistress for anyone or pour sulfuric acid on anyone even though I myself almost got killed by Mumu which is my own issue it did not affect other people except that what bad things have I done in my life?]

$(\text { Guo 2000, 38) })^{2}$

Fig. 1. Fenfang's stream of consciousness about her past mistakes and its visual effects on the page 
While one can only imagine the different challenges these formalistic features may present to the translator of the novel, Xiaolu Guo's strategy to overcome them is both drastic and creative. After Chatto \& Windus expressed interest in publishing an English version of the novel, she rewrote it based on an English translation done by Rebecca Morris and Pamela Casey. Compared to the 256-page long Chinese edition, this reedited English version, published in 2008 under the title 20 Fragments of a Ravenous Youth, has 202 pages with a much sparser layout. More than half of the original content has been left out, and the eight musical notes marking the eight long chapters have been replaced by 20 fragments of Fenfang's life, which are still told in first person narration. ${ }^{3}$ Fenfang's stream of consciousness in the chunks of free-flowing Chinese characters disappear in the English version, which employs much simpler stylistics and contains a larger proportion of dialogues. Moreover, the name of Fenfang's American boyfriend in the English translation is Ben, who plays a much lesser role in the protagonist's life. Not only is Ben the lover who only exists in international phone calls, but the entire ending about the plane accident and his mysterious disappearance has also been cut out, making the English version much less dramatic in terms of plot. Compared with Fenfang de Sanshiqiduer, this reduced role of Ben has also reduced the level of bilingualism in 20 Fragments of a Ravenous Youth.

As a result of these drastic changes, it would perhaps be more accurate to describe the 2008 version as a translingual adaptation, rather than strict translation, of the 2000 version. Indeed, 20 Fragments of a Ravenous Youth is very much presented and marketed as a new book written by Guo. This is confirmed by paratextual details: the names of the translators only appear in small letters in the front matter page and in Guo's acknowledgement at the end of the book, and the cover design of the English version, featuring the direct gaze of a youthful Asian woman drinking bubble tea, creates an exotic ambience and thus gives away its commercial aspirations (see Figure 2 and 3 for a comparison). It is therefore not surprising that the preface of the 2000 version, in which Guo makes a complaint about the increasing commercialization of literature-"writing in our time is not really writing, it is a kind of selling (chumai)"-is nowhere to be found in the 2008 version (Guo 2000, 2). Instead, Guo tells her Anglophone readers about the significant revisions she has done, managing their impression about the book as something refreshed, or rather, reborn:

... I was no longer completely happy with the original Chinese text. Ten years on, I found I didn't agree with the young woman who had written it. Her version of the world had changed, along with Beijing and the whole of China. I wanted to rework each sentence of my Chinese book, and fight with its young author who knew so little about the world ... To rewrite a Chinese book when it has already been translated is a big 

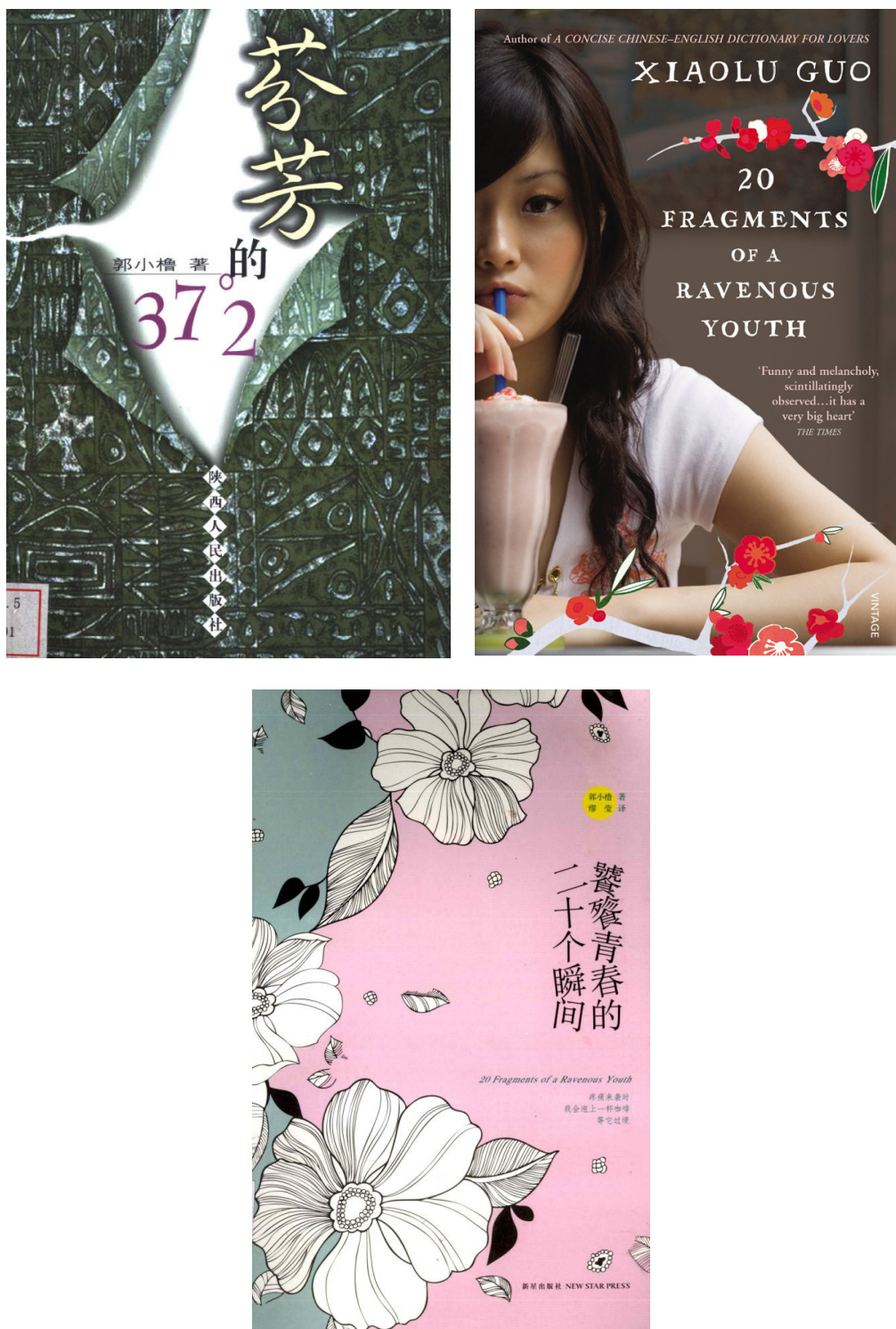

Fig. 2, 3, and 4. Cover designs for the 2000, 2008, and 2010 editions of Fenfang's story (in that order)

burden to place on a translator. The only way to do it was to write in English over the top of the translated text. (Guo 2008, 203-204)

In the most literal sense, 20 Fragments of a Ravenous Youth is a text that has been reborn in translation, and this rebirth warrants critical reflections on the ways we discuss translation and world literature. When Rebecca Walkowitz proposes the concept of "born translated," she is referring to literary works in which "translation 
functions as a thematic, structural, conceptual, and sometimes even typographical device" (Walkowitz 4). Translation is understood as something that happens in the textual world created by the writers, who "pretend to write in another language" (22). For her, literary works become world literature when translation is "not secondary or incidental to them" but "a condition of their production" (4). To explain her idea in simpler terms, a novel written entirely in Chinese can count as "born translated" as long as it features foreign characters who supposedly communicate in different languages other than Chinese. The importance of such born translated qualities, according to Walkowitz, lies in the fact that it makes consumers of these texts aware that they are not "native readers," because the stories unfolding on the page are supposed to have taken place in languages different from the one they are reading in (6). Hence, both Fenfang de Sanshiqiduer and 20 Fragments of a Ravenous Youth qualify as texts "born translated," because Fenfang is a bilingual character who interacts with other characters in different languages on different occasions. Readers of both versions, even if they are bilingual themselves, could only see predominantly monolingual representations of these interactions on the page, which demand them to actively imagine how Fenfang lives a cosmopolitan life in Beijing with her linguistic and intercultural communication skills.

However, there is a problem with Walkowitz's definition of translation as a text's internal act of creative imagination-it is too broad and too narrow at the same time. On the one hand, it is too broad because if being "born translated" simply means telling foreign-language stories in one's working language, most of the colonial and Orientalist literatures that proliferated at the height of Western imperial conquests, such as those by Henry Rider Haggard and Sax Rohmer, would qualify as world literature and generate a negative impact on its development as a progressive discipline. ${ }^{4}$ On the other hand, it is too narrow because any discussion on world literature and translation should not lose sight of the very basic definition of the latter, namely translation as movements between different linguistic and cultural systems. More specifically, as Guo's practice of collaborative translation and rewriting shows, these movements are often plural and multi-directional and constitute creative acts of their own. It is thus my observation and contention that translation as creative rebirth makes multiple versions of the same story, often to the extent that this notion of the "sameness" between different versions becomes too nebulous to be located. They demonstrate an author's willingness to engage with different audiences and contexts. As such, the translational aspects of a given set of texts are not limited to their thematic treatment and discursive representation of translation or cross-linguistic communication in general. Instead, they are the very means through which organic connections among different versions of texts are established and authorial agency is channeled. 
In theory, there should be no limit on such translational rebirths as long as there is enough artistic and material interest for the linguistic movements to be sustained or multiplied. Even if it is just between two languages, a text can still loop back and forth, creating a translational boomerang that undermines the very singularity of the text. In 2010, 20 Fragments of a Ravenous Youth was translated back into Chinese by Miu Ying, the same translator who took up the impossible task of translating Guo's broken English in A Concise Chinese-English Dictionary for Lovers. The 2010 Chinese version, Taotieqingchun de Ershige Shunjian, faithfully renders the fragmented aesthetics and simplified stylistics of the 2008 English version, which gives off an impression that Miu Ying has not consulted the 2000 Chinese version at all. Indeed, the 2010 version is once again presented to Chinese readers as a new work by Xiaolu Guo, and the translator has been given due recognition on the cover of the book to indicate its status as a freshly translated novel by a bilingual Chinese author (see Fig. 4). There is neither an anti-commercial preface nor an acknowledgement for collaborative editing and translation in the 2010 version, and it seems that Guo has stuck to the conventional role of a translated author this time, leaving the process entirely in the hands of her Chinese translator. As a result, many of the revisions she has made to the 2008 version, especially Fenfang's occasional statements about Chinese people and culture, are preserved in the 2010 version and can read too generalizing for Chinese readers.

For example, in the third fragment of 20 Fragments of a Ravenous Youth, Fenfang remembers her first encounter with her ex-boyfriend: "Then he asked my age, and I asked his. That's the tradition in China. If we know each other's ages we can understand each other's past. We Chinese have been collective for so long, personal histories are not worth mentioning" (Guo 2008a, 19). An addition that is not in the 2000 version, Fenfang's brief thought here functions as a rather generic explanation about Chinese culture for the book's Anglophone readers, who, in Guo's assumption, know little about the significance of collectivism in China. In other words, it is only through an understanding of the significance of collectivism in Chinese culture that Guo's Anglophone readers can appreciate how Fenfang and her boyfriends stand out in that culture as individualists, as characters with strong personalities. However, when faithfully translated back into Chinese in the 2010 version, such statements appear at best redundant and unnatural, and at worst generalizing and self-exoticizing, especially considering that the Chinese readers of the 2010 version are aware that they are reading something "originally" written in English by a diasporic Chinese author, while the Anglophone readers of the 2008 version are encouraged to believe that what they are reading has been more or less (re-)written in English by the author. Therefore, it is fair to say that due to the lack of creative input from Guo, the 2010 version is a much blander text that does not cater to its target readership as much as the 2008 version. It is then no surprise that compared to 20 Fragments of a Ravenous Youth, which was moderately successful 
commercially and got long-listed by the Man Asian Literary Prize, Taotieqingchun de Ershige Shunjian has not had much market presence nor critical recognition in China.

Despite the different degrees of success Xiaolu Guo has had with these different versions of Fenfang's stories, the translational boomerang she has actively engaged in not only demonstrates her willingness to maximize her literary presence in China and abroad (no matter in which language she is writing) but also showcases the productive role multilingual authors can play in the translingual circulation of their works. Among the academic debates on the concept, there has always been the hackneyed promotion of world literature as articulating "universal truths about the human condition ... and accessible to everyone, regardless of linguistic differences and the use of translations and other cultural filters" (Larsen 27). Many writers that literary critics associate with world literature, such as Gao Xingjian, often echo this statement by emphasizing how they "do not think about the reader at all" in their writing (Lee and Dutrait 743). Guo's active participation in the translation processes offers a different modus operandi for world literature that circulate in multiple languages. It differentiates her from earlier generations canonized under universalist and transcendentalist claims. The translational boomerang requires the author to be worldly. To be worldly is to be unafraid to assert her creative agency over the remaking and reception of her works when they cross boundaries, which are not limited to the textual but often extend to the realm of the visual as well.

\section{TRANSLATIONAL VISUALITY: UFO IN HER EYES, 2009 AND 2011}

Soon after she finished rewriting Fenfang's stories in English, Xiaolu Guo embarked on another literary project, one that was not like anything else she had written before. UFO in Her Eyes, published in 2009, was a breakaway from the semi-autobiographical style of her previous works. It presents a series of incidents in a poor rural Chinese village called Silver Hill after a young woman, Kwok Yun, declares that she sighted a UFO and rescued a white man with a snakebite from the rice fields. The village chief, Chang Lee, takes great interest in her story after an English letter arrives from New York. The letter is enclosed with a check for \$2,00o US dollars. It is an expression of gratitude of its sender, a man named Michael Carter, who identifies himself as "the County Executive of Suffolk County" and the man saved by Kwok Yun (Guo 20o9b, 80). While the UFO incident remains unverified throughout the story, Guo's depiction of the farce of modernization following the arrival of the letter becomes the main focus of the novel. The village

bureaucrats are quick to turn rumors about the UFO into tourist and development 
opportunities, causing great disruptions in the villagers' traditional way of life. The story ends with a bleak picture for Silver Hill: now a "model peasant," Kwok Yun enters an arranged marriage with Headmaster Yee Ming, the local fish farmer, Li Sheng, commits suicide after the village leaders build a tennis court over his fish pond, and Chief Chang is murdered by butcher Ling Zhu, who lost his job due to strict standards of food hygiene introduced as part of the village's modernization plan.

Notwithstanding the surrealist stories it tells, UFO in Her Eyes continues Guo's formalistic experiments in fiction writing. The novel consists of four X-files and three appendixes related to the incidents in the village, and these files contain interviews with different villagers conducted by government agents, letters and email correspondences between bureaucrats, and map sketches showing the changing geography of Silver Hill before and after the sighting of the UFO. Maya Jaggi, in a book review for The Guardian, comments that these formalistic experiments make the book "a sometimes-frustrating halfway house between novel and screenplay" (Jaggi). Admittedly, the interview format and the rustic speech habits of its characters partially captured by Guo's minimalist use of the English language do lend the novel much cinematic ambience germane to further visualization. Indeed, the book was soon adapted into a Chinese-language film script, with which Guo directed her second feature film, UFO in Her Eyes (2011). In fact, the idea of the film came before the novel, as Guo explains in a podcast interview in 2019:

Ten years after I left China, I thought I can probably make a bigger film, a very dramatic film about the political situation in China ... how a village is a kind of symbol for the whole country, and how the village represents this idea of ideological warehouse, the idea of socialism, and then communism, and then capitalism became useful, all these big ideas, ideological things, become just pure practical matter as long as you can use [them] to make economic growth then we do it ... So I thought, how to write that story? I need some surreal elements, such as UFO, animals . . . It would be very difficult if I write [it] as a film script because it would be a quite mad script with peasants talking and animals talking, and there is a UFO and all that. And it would be very difficult to find funding... how can I convince the producers? Then I thought maybe I should write it as a novel first. When the novel is published in different countries, then I might have more possibilities to find funding. So, I wrote [the novel] in English while I was living in Paris studying French, but the whole conversations, the dialogues, the narratives are in Chinese of course. It is set in a village in China. So linguistically it was very strange for me to, you know, translate, not only linguistically but culturally, and metaphorically ... (Guo 2019) 
This quote provides at least three important revelations about UFO in Her Eyes as a set of textual-visual works. Firstly, both the novel and the film are "born translated," but in different ways. The novel, written in English but set in a rural village in China, is born translated in Walkowitz's sense. Except for the letters between Silver Hill and the American man, all the interviews and email communication the readers read in English on the page, are supposed to be in Chinese. Different from A Concise Chinese-English Dictionary for Lovers, which describes events that have taken place in English in Europe, and 20 Fragments of a Ravenous Youth, which Guo revised in English based on an existing translation, UFO in Her Eyes is the first novel completely set in China that Guo has had to construct in English from the very beginning. As Guo admits, writing the novel involves a kind of "strange" translation, one that requires her to constantly think about how the ways in which particular Chinese characters speak can be captured in English expressions. Reversely, to follow the story, the Anglophone readers have to imagine the sociocultural dynamics between different dialects of Chinese based on what Guo presents to them in English; even without knowing any Chinese, they are still able to do this because it is the sociolinguistic tension between different dialects that they have to understand, rather than the dialects per se. For example, there is a nameless bicycle mender in the village who is a migrant worker and supposedly speaks a dialect no one can understand, which frustrates the government agents (Guo 2009, 57). One of these agents has been sent from Beijing and he constantly relies on the local Hunan agent for the interrogations because the villagers do not speak Mandarin well. These linguistic differences are important because Guo uses them to highlight the subaltern position of rural subjects in contemporary China as well as the Chinese political leaders' failure to communicate with them.

In contrast to the imaginative processes of translation embedded in the fictional world of the novel, the making of the film requires translational rebirths in a more literal sense. Shot in a rural village in Guangxi province, the film has a large Chinese crew and employs accented Mandarin as its main language. In another interview with a Chinese magazine, Guo stresses that translating an English novel about China into a Chinese film script is a very demanding task and she dealt with it by writing the film script bilingually, meaning that she first adapted the novel into an Englishlanguage film script and then self-translated it into Chinese (Han). In other words, UFO in Her Eyes the film is reborn translated at both linguistic and visual levels. The process of its creative adaptation from the novel is thus both translingual (from English to Chinese) and trans-media (from textual to audiovisual). 


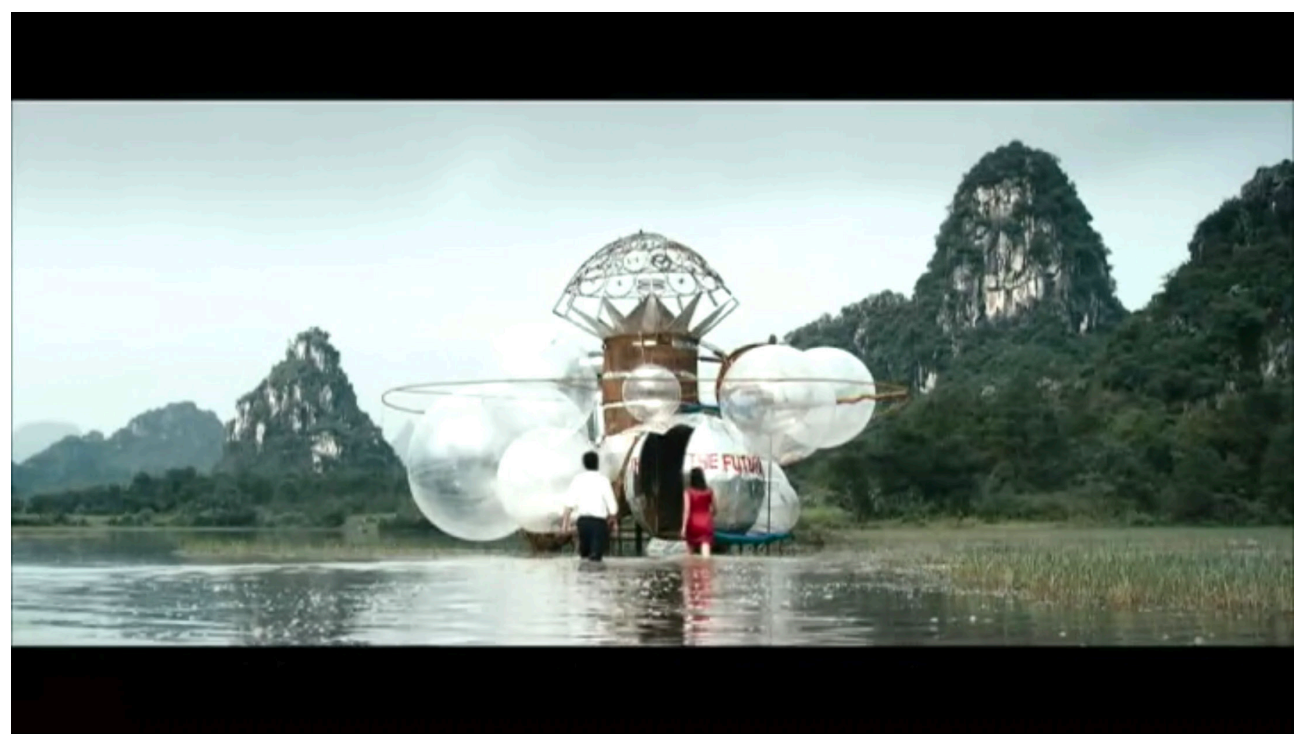

Fig. 5. Kwok Yun and the bicycle mender board a UFO at the end of the film

Secondly, Guo's comments about funding reveal her strategic thinking on the divergent uses of different media forms and how to manipulate them to her advantage. As an arthouse filmmaker who does not rely on box office earnings for financial return, Guo was aware that making a surrealist film set in China would be costly. Indeed, she confesses later, in the same interview, that most of the funding she got was used to construct the UFO model that appears in the end of the film (see Fig. 5). To make the story appealing for potential funding bodies and producers, she chose to write a novel first. Apart from the fact that writing a novel is a much easier task that does not involve much teamwork, Guo's choice was based on an unapologetic recognition that her novels are more commercially oriented than her films. Written entirely in English and presented as a series of censored documents, the novel is much more accessible to Anglophone consumers than the film, since the film presents all the dialogues in Chinese and dives directly into a local cultural context unfamiliar to most audiences.

The different uses of these two media forms in Guo's creative universe can partly be seen in the contrast between the cover of UFO in Her Eyes (2009) and the poster for UFO in Her Eyes (2011). On the one hand, similar to that of 20 Fragments of a Ravenous Youth, the 2009 book cover is again a close-up of a beautiful Asian woman, and she has on her face a red Chinese seal with some Chinese characters that do not make any sense - an exotic Orientalist feature to entice curious readers who cannot read the Chinese characters to buy the book (Fig. 6). On the other hand, the 2011 film poster takes the content of the story much more seriously as it juxtaposes the 
UFO with the flood of tourists coming to the rice fields of Silver Hill, maximizing the satirical and subversive messages Guo seeks to deliver (Fig. 7). Although to what extent Guo as author has control over the design of these paratexts is hard to say, her awareness about how her books would be treated and compromised as literary commodities is clear in her comment, which is my emphasis here. It was with this awareness that she adapted herself to the commercial logic of the book market in order to acquire more freedom for her filmmaking.
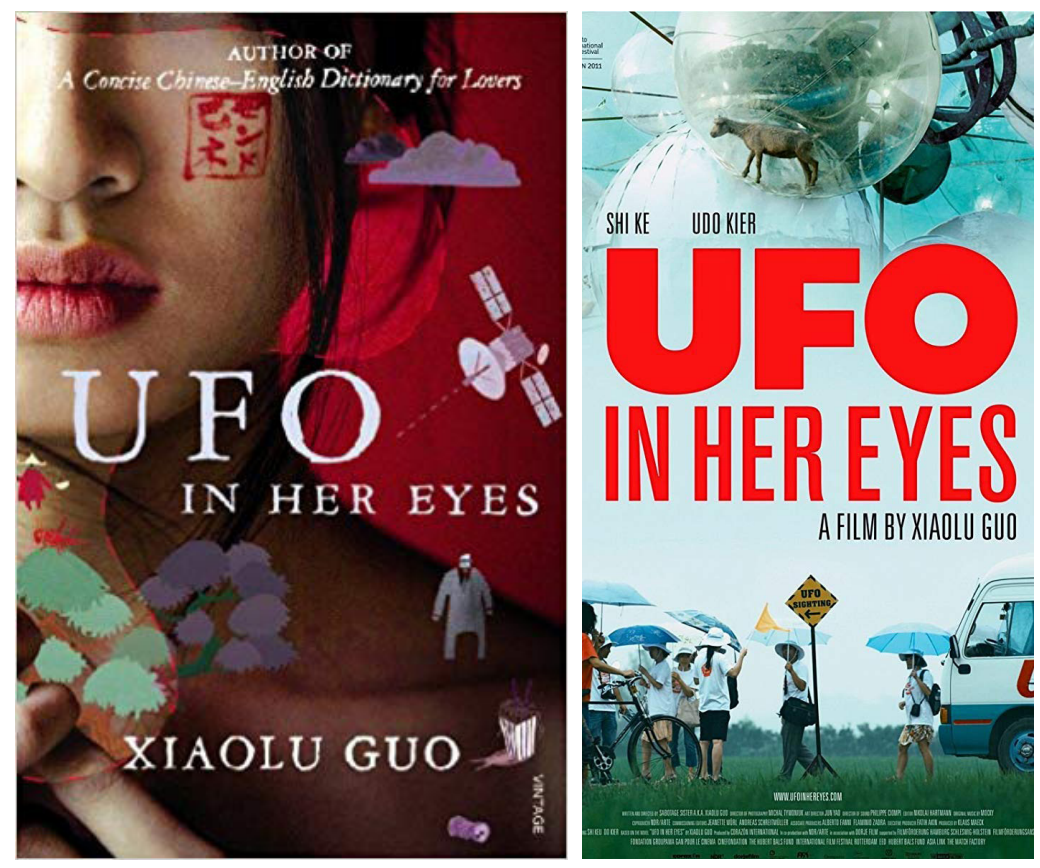

Fig. 6 and 7. UFO in Her Eyes, book cover (2009) and film poster (2011)

Moreover, Guo utilizes the artistic purchase she has with the film genre to add more formalistic elements to the surrealism of the story, in terms of both the plot and its visual representation. Rather than accepting marriage with Headmaster Yee as arranged by the village, Kwok Yun in the film version of the story falls in love with the bicycle mender and elopes with him by boarding a UFO he has built after his decrepit house is destroyed by the modernization project of the village. With the English words "THIS IS THE FUTURE" painted on one of its balloonlike components, the UFO contains as their fellow passengers a range of domestic animals, including a chicken, a goose, and a goat, resembling a Chinese Noah's Ark that would help them escape from the absurd chaos of village life as it gets trapped in the greed of capitalistic development. In addition, as Guo has hinted 
in her interview, the animals do have a more important aesthetic function in the film. Although they do not talk, the film on several occasions presents the human farce in the village through their points of view. For example, one of Chief Chang's publicity stunts to showcase Silver Hill's progress of modernization is a "Learn from Miss Universe" beauty pageant, which involves young women in revealing clothes walking and dancing on a makeshift stage, and commercial leaflets are distributed to the audiences encouraging them to change their hairstyle and outfit. Also placed on the stage as a symbol of this beauty campaign is a peacock, and when its point of view is presented, the picture of the humans dancing on the stage becomes distorted for a few seconds (see Figs. 8 and 9). Foreshadowing the animals' presence in the bicycle mender's UFO, such non-human perspectives serve as reminders of the absurdity of a human world devoured by extravagance and folly.

Fig. 8 and 9. The distorted human world in the eyes of a peacock
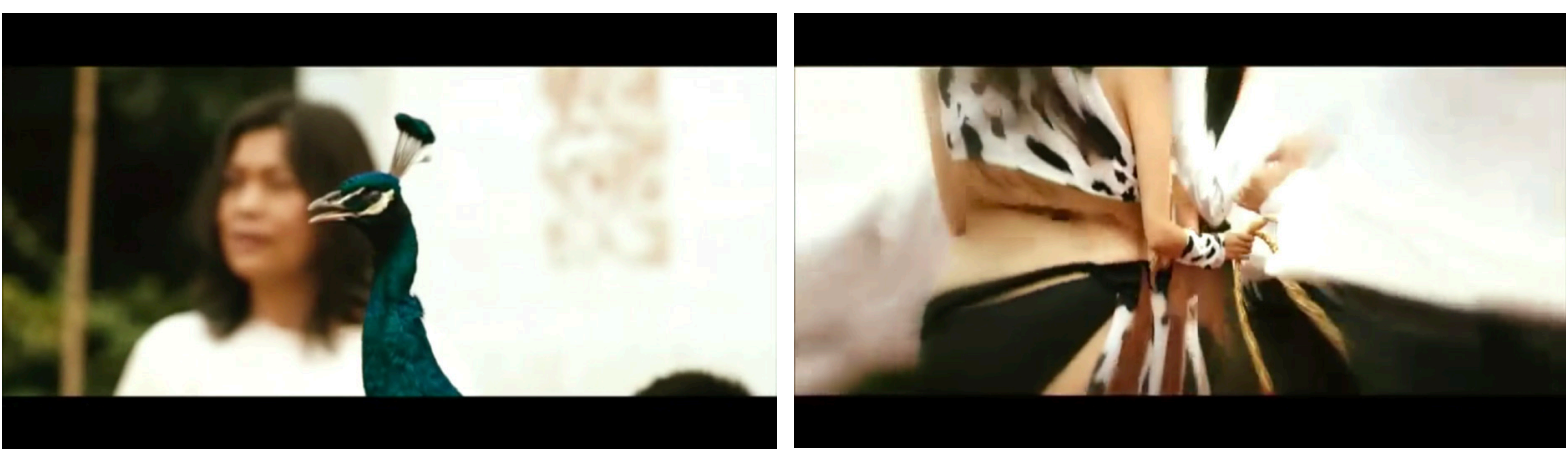

Lastly, it is clear that Guo has always intended for the story to be a political allegory about contemporary China. In Guo's conceptualization, the rural village, rather than the metropolis in Fenfang's stories, is a more suitable symbol for "the whole country" (from the long quote at the beginning of this section). Contrary to images of big Chinese metropolises, which often appear on postcards and government propaganda materials and serve as proofs for the scale of Chinese modernity or as celebrations of the nation's progress and success, Guo's focus on the rural village diverges from such obsession with modernity as a desirable end result. Instead, the dramatic transformation of the rural village in both the novel and the film serves as a poignant reminder of the superficial and destructive aspects of modernization and thus challenges the neat narratives of global capitalistic advancement from a local position. 
Combining political satire and national allegory, UFO in Her Eyes as a set of textual-visual works seems to fit into Frederic Jameson's much criticized statement that "all Third World narratives are ... necessarily ... national allegories" (Jameson 69). As many postcolonial critics would point out, the issue with Jameson's statement is that it could be easily (mis-)interpreted as a denial of Third World, or non-western, writers' agency to create works about individual characters that resonate universally. For example, Rey Chow, citing Étienne Balibar, states that there has been a dominant trend in the West to understand cultural products from the non-West only through the lens of "anthropological culturalism," reducing artistic works to social documents (Chow 14). Similarly, Shu-mei Shih identifies "the allegorical" as a mode of cultural production that sustains the First World's "stereotyped knowledge" about Third World nations (20). She stresses that the popularity of the Third World national allegory results from not only the preference of the western market but also diasporic writers' complicity with it. As the exotic design of the book cover shows, it is undeniable that Xiaolu Guo has complied with western market force to some extent, and thus she may be accused of portraying a negative image of China for the sake of performing a certain kind of expected antiestablishment criticality for her western readers and viewers.

However, Guo makes clear in the novel that the political situation in China she satirizes via this national allegory cannot be separated from the larger international environment, where American hegemony dominates subaltern subjects' conceptualization of modernity and progress. During an interview with the government agents, Kwok Yun reveals that Chief Chang gave her a lecture about the galaxy after she reported the UFO sighting. When asked the question "who does the sun circle round?," Chief Chang gave the following explanation, which is obviously more political than scientific:

I hope you realize that is a political question! We Chinese used to be our own sun, you know. Think of the characters that make up the word China: 中国 - Zhong Guo, a country in the center of the Universe. We used to stand still, we didn't need to circle around anyone, and others had to circle around China! But unfortunately, in the last century, we were attracted by the Soviet Union, before it fell apart. And now, we are attracted to ... no, it's more than attraction, we are actually circling around ... the USA.

(Guo 2009, 70)

Kwok Yun then confirms that "she [Chief Chang] also said America is the sun for the Chinese government" (71). In the film version, this America-centrism is further dramatized via the physical presence of the American mayor, who makes a grand visit to the village and is invited to a splashy wedding banquet by Chief Chang. The debauchery of the banquet is juxtaposed with the riots that have broken out in a nearby construction site, where people's protests against government plans to build 
factories on their land are getting increasingly violent. In between these chaotic scenes of indulgence and rancor, the American man shouts a drunken toast to the villagers: "The people of this village are the future, and China!" (Fig. 10) The image of the American mayor here is definitely not positive. He arrives in a flamboyant helicopter, and seemingly overwhelmed by the villagers' intense hospitality, he has nevertheless been very quick to join the carousal, dancing with a small American flag in his hand.

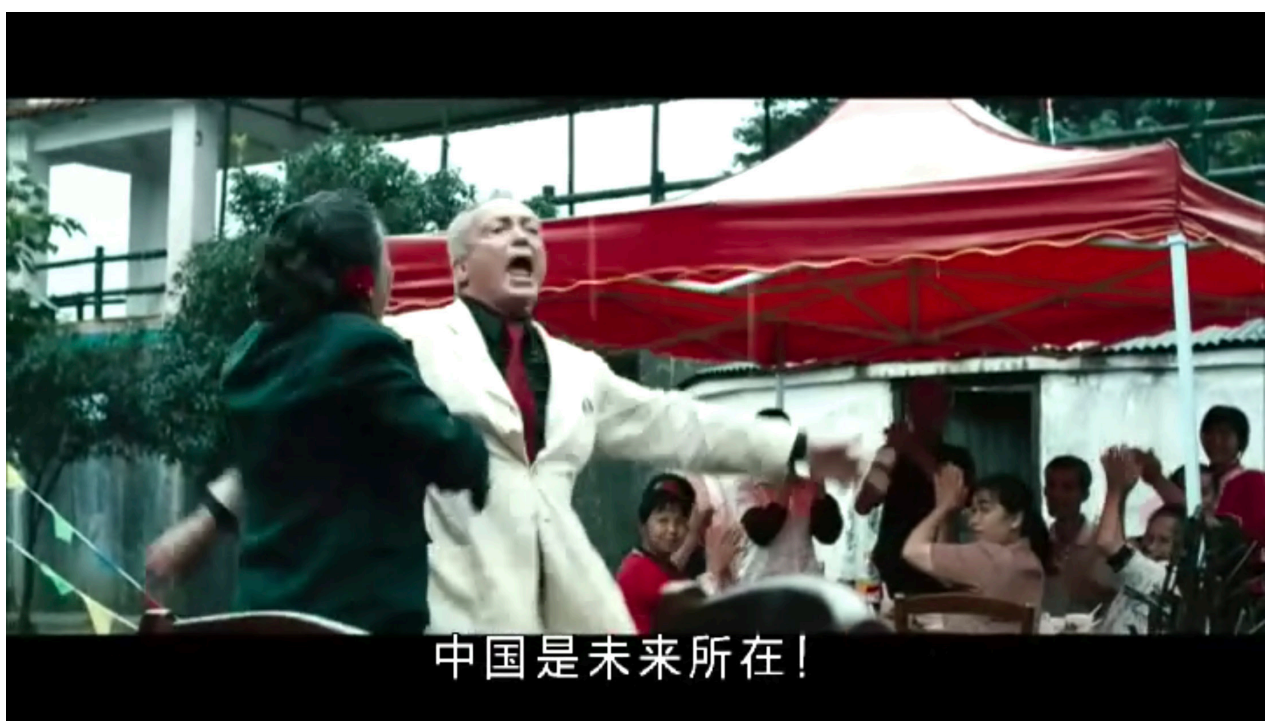

Fig. 10. The American mayor gets drunk and shouts "China is the future!"

Therefore, rather than capitalizing on some kind of stereotypical binary of backward East versus progressive West, Guo's localized critique of modernization is conspicuously multi-directional. American hegemony, the Chinese rush towards capitalistic modernity, and the superficiality and hypocrisy of local bureaucracy are all amplified and mocked in UFO in Her Eyes. Chief Chang's pragmatic theory of America-centrism in the novel and her exaggerated sycophancy towards the white man in the film represent the kind of self-Orientalism at the heart of Chinese modernization projects that Guo seeks to highlight and criticize. Therefore, I would argue that before we accuse Guo of damaging China's image to please the West, we must not ignore her heightened awareness about such issues and should acknowledge her equally critical attitude towards the hegemonic forces emanating from the West and Chinese people's romanticized obsession with the West. As an Anglophone diasporic writer based in the West, Guo inevitably faces issues 
of self-Orientalism in her career, including the demand for her to represent "the Chinese" via modes of writing such as "the allegorical" and the ways in which her works are marketed that she may not have full control of. However, it is exactly against such involuntary involvement in these self-Orientalist market forces that she can deploy certain anti-hegemonic preemptive tactics in the fictional worlds she creates. Similar preemptive tactics can be found in Guo's other works as well. For example, her 2014 novel, I Am China, contains a scenario where a London publisher seeks to capitalize on a Chinese love story by framing it as a political scandal for the entire nation. Such fictionalization of the commercial drive behind the development of translated literature in the West constitutes a kind of "meta-allegorical" comment on the reductive capitalistic logic that Guo herself is constantly caught in and thus functions as a kind of artistic catharsis via which Guo can utter subtle critiques against the Anglophone publishing industries from the inside (Shi 2016, 28).

In contrast to the clichéd image of a solitary writer indulging in her own imagination to create highly individualistic yet universal stories, Xiaolu Guo is an auteur engagé who works across linguistic and cultural divides with a strong awareness of the different challenges and limits she may face in different contexts. This awareness is channeled back into her creative processes as she proactively adjusts narrative contents and forms to maximize her agency vis-à-vis political pressure and market expectations. As a result of these creative processes, what I call translational visuality is captured in the evolving vision of stories that is present throughout the multilingual creation of a set of texts. From the idea of an allegorical film about Chinese society and politics to a novel written in English, and then from a bilingual script to a Chinese-language film shot in rural China, UFO in Her Eyes is a set of textual-visual works constantly reborn translated. Like Fenfang's stories, they cannot be reduced to a singular object or moment of making, or any original location from which circulation and adaptation begin. This translational visuality of UFO in Her Eyes is not only a creative byproduct of Guo's bilingualism but also the strategic outcome of her experience in navigating the complex intersections of political, economic, and cultural dynamics imposed on diasporic and transnational artists.

\section{MINOR LITERATURE, WORLD AUTHOR}

In its focus on the phenomena of translation and adaptation, or, as I have called them, the processes of creative texts being "reborn translated," this paper has so far emphasized the more active role multilingual authors can play in the circulation and reception of their works. My proposal for a shift from "world literature" to 
"world author" in the discussion on the production and circulation of translational and translated works may seem to run contrary to what Xiaolu Guo suggests in the opening quote of this paper-that art is beyond the artist's politics. After all, after Roland Barthes's well-known declaration about "the death of the author," shouldn't we care more about the art produced by the artist, rather than the artists themselves? (Barthes 142)

As the previous sections have illustrated, the method I have adopted to studying Guo as a world author involves different combinations of close reading, background investigation, as well as analytical attention to paratextual arrangements. It is definitely not my intention to suggest a retrogressive movement back to biographical studies of literature and art. Rather than coming up with yet more essential(ist) criteria against which world authors can be measured and categorized as such, my use of this term is largely strategic. Similar to how the word auteur is used in discussions about film directors with strong stylistic characteristics, the term "world author" encourages critical analyses of different authors' creative practices in multiple texts across genres and media forms and views their (re-)construction of textual worlds in relation to the world literary marketplace where these textual worlds circulate as material objects of culture. Under such examinations, these creative practices may form holistic styles of artistic production and self-promotion, or they may be occasionally contradictory to one another as the auteur engagé attempts to achieve different goals among different readerships and audiences. More importantly, the multiplicity highlighted by the concept of world author fills a void in current academic discourses on world literature as a rising field of study. Whether it is David Damrosch's definition of world literature as texts that "circulate beyond their culture or origin" (Damrosch 8), or Pascale Casanova's insistence on world literature being recognized in a Euro-America-dominated "international literary space" (Casanova 25), or Pheng Cheah's emphasis on texts' "world-making" power as "an ongoing, dynamic processes of becoming" (Cheah 30), these conceptualizations of world literature pay much more attention to the internal qualities or the external structures of power that determine a text as such than the inter-and para- textual connections among clusters of works in l'ouvre d'un auteur that effectively deconstruct the very singularity of une oeuvre d'art. In other words, the shift from "world literature" to "world author" is not to substitute the artist's creation with his or her intention; it is rather an invitation to discover and uncover a wider range of creative practices beyond the singular work, textual, visual and more.

This shift toward holistic multiplicity is a particularly effective way for practitioners of minor literature like Guo to obtain more visibility and influence in the disciplinary space opened up by academic discourses of world literature. Although Guo works in two of the world's most widely spoken and powerful 
languages, the in-between space she occupies in the transnational flows of human communication and capital accumulation has put her in minor positions in relation to a multitude of dominant cultural formations. Firstly, as Gilles Deleuze and Félix Guattari propose in their discussion on Kakfa, minor literature refers to "minority constructs within a major language" and is characterized by being political and collective at the same time (Deleuze and Guattari 16-17). Guo's Anglophone works certainly fit into this definition as Chinese accents and cultural misunderstandings are often highlighted in the stories she tells. Her adoption of "the allegorical" as a mode of storytelling is politically subversive and at the same time challenges expectations for her to represent collective values. Secondly, since she moved to Europe, she has stopped writing new novels in Chinese, but preserves her presence in the Chinese-speaking world as she transforms her position from a young female author from a small village in South China to a translated diasporic Chinese author based in London. Translated literature naturally occupies a minor position in China where hundreds of thousands of books written in Chinese are published every year, and as a Chinese diasporic author who writes English works about China that are often difficult to translate, Guo's position within the wider Chinese literary field is a kind of minor of the minor. Lastly, as a bilingual filmmaker who focuses exclusively on arthouse features and low-budget documentaries, Guo's place in the global circulation of visual culture is again minor, especially in relation to the mainstream commercial films with wide releases and significant box office revenues.

However, Deleuze and Guattari have also made a rather paradoxical statement with regards to minor literature at the end of their essay: "There is nothing that is major or revolutionary except the minor. To hate all languages of masters" (26). What they mean is that the minor has the power to subvert the major from within but does not necessarily have to become the major that dominates other minors. No matter whether it is rewriting a published Chinese book based on an existing English translation that is to be translated back into Chinese as a new book, or writing an English book about China as part of the financial preparation for its adaptation into a Chinese-language film, Guo's artistic practices have shown us that it is possible for a constellation of minor positions to form strategic coalitions with one another and obtain visibility and influence without becoming the major.

Moreover, it is exactly by accommodating and promoting such revolutionary power of the minor that world literature serves its most pragmatic purposes. Firstly, world literature offers a disciplinary space broad enough to counter the categorizing impulses prevalent in the identity politics of existing academic paradigms. As a bilingual diasporic author, Guo does not fit well in the national conceptualizations of Chinese literature or British literature, nor is the postcolonial paradigm working well to accommodate her considering the different power dynamics between China and the West. By contrast, the cultural nuances in her management of national and 
international politics can be more fully explored in an inclusive field like world literature. World literature can also accommodate the many other languages into which her works have been translated, and investigations on these translations may further revise the arguments put forward in this paper, as they are naturally limited by its scope. Secondly, world literature, compared to comparative literature, takes translation much more seriously. Rather than focusing on "the original" in multiple languages, critical world literature studies can investigate translational elements within a multilingual text as well as the acts of translation in the multiple re-makings of texts. Lastly, as I have argued in this paper, the discipline of world literature itself can benefit from a shift from singular texts to more holistic approaches to the multiplicity of authors' creative practices. After all, before our current age of global capitalism gets totally post-humanized by AI and robots, people are still the majority creator of artistic objects and ideas and may very well move around in ways much more complex than the things they create, and as such, humanist questions like the one Guo raises in the opening statement will continue to be asked. 


\section{Notes}

1. Unlike dissident writers such as Ma Jian and Liao Yiwu, Xiaolu Guo is far from being a "banned author" in China, even though she has kept a distance from the country's mainstream cultural institutions since she left in 2002. The majority of her literary and cinematic output remains accessible in China, and fictional works with themes that may be sensitive for the Chinese establishment, such as UFO in Her Eyes (2009) and I Am China (2014), have simply not been translated into Chinese. Guo has also been traveling back to China and maintains some connections with the cultural circle there. For example, in 2012 she was selected as one of the 20 authors representing China in the London Book Festival, alongside Mo Yan, Liu Zhenyun, Alai, Xu Zechen and many other prominent figures, all of whom have massive followings among Chinese readers at home (Guo Jun). In 2015, she also served as one of the judges of the Inaugural China Bookworm Literary Award, which was established by an international group of translators and critics in Beijing.

2. This quote is translated by me here because this passage has been deleted from the 2008 English version.

3. The chapter titles in the 2008 version are thus much longer, such as "Fragment Five: A Mao drawer doesn't prevent Fenfang from ending up at the police station," "Fragment Fifteen: New Year and Fenfang eats a bowl of her mother's longevity noodles," etc.

4. Walkowitz is not the only critic who has such content-oriented views of the "translational." Waill Hassan has a similar definition of "translational literature" as texts that stage "acts of translation as formal, thematic, aesthetic, or ideological elements" (1436). By limiting the "translational" to arrangements internal to a given text, they risk losing sight of the translingual movements external to it, especially when these movements constitute writerly practices that challenge the very singularity of the text at hand. While I appreciate their effort at broadening the role of translation in the making of world literature as such, it is this latter kind of "translational" I focus on in this case study of Guo, which is integral to how I seek to revise the text-focused debates in world literature via the concept of "world author" in the ending section of this paper. 


\section{Works Cited}

Barthes, Roland. Image, Music, Text. Translated by Stephen Heath, Hill and Wang, 1977.

Casanova, Pascale. The World Republic of Letters. Translated by M. B. DeBevoise, Harvard UP, 2004.

Cheah, Pheng. "What is a World? On World Literature as World-Making Activity." Daedalus, vol. 137, no. 3, 2008, pp. 26-38.

Chow, Rey. The Protestant Ethnic and the Spirit of Capitalism. Columbia UP, 2002.

Damrosch, David. What Is World Literature? Princeton UP, 2003.

Deleuze, Gilles, and Guattari, Félix. Kafka: Toward a Minor Literature. Translated by Dana Polan, U of Minnesota P, 1986.

Dervin, Fred, and Gao Minghui. "Representing the Chinese Students in Fiction: The Case of A Concise Chinese-English Dictionary for Lovers." Chinese Educational Migration and Student-Teacher Mobilities: Experiencing Otherness, edited by Fred Dervin, Palgrave Macmillan, 2015, pp. 39-58.

Doloughan, Fiona. "Translation as a Motor of Critique and Invention in Contemporary Literature: The Case of Xiaolu Guo." Multilingual Currents in Literature, Translation, and Culture, edited by Rachael Gilmore and Tamar Steinitz, Routledge, 2017, pp. 150-167.

--. "The Construction of Space in Contemporary Narrative." JNT: Journal of Narrative Theory, vol. 45, no. 1, 2005, pp. 1-17.

Gilmour, Rachael. "Living between Languages: The Politics of Translation in Leila Aboulela's Minaret and Xiaolu Guo's A Concise Chinese-English Dictionary for Lovers." The Journal of Commonwealth Literature, vol. 47, no. 2, 2012, pp. 207-227.

Guo Jun 郭军. "Yingguo yaoqing moyan annibaobei deng zhongguozuojia canjia lundunshuzhan (英国邀请莫言安妮宝贝等中国作家参加伦敦书展) [The UK invites Mo Yan, Annibaobei and other Chinese writers to the London Book Festival]" ydbook, 12 Apr. 2012, www.ydbook.com/seph/bkview.asp?bkid=226470\&cid=683794. Accessed 23 Oct. 2020.

Guo, Xiaolu 郭小橹. Fenfang de sanshiqiduer (芬芳的三十七度二) [Fenfang's 37.2 Degrees]. Shaanxi renmin chubanshe, 2000.

--. Woxinzhong de shitouzhen (我心中的石头镇) [The Stone Village in My Heart]. Shanghai wenyi chubanshe, 2003.

-.. Village of Stone. Translated by Cindy Carter. Chatto \& Windus, 2004.

-.. A Concise Chinese-English Dictionary for Lovers. Chatto \& Windus, 2007.

--. 20 Fragments of a Ravenous Youth. Translated by Rebecca Morris and Pamela Casey. Chatto \& Windus, 2008a.

--. Lianrenban zhongyingcidian (戀人版中英詞典) [A Concise Chinese-English Dictionary for Lovers]. Translated by Guo Pingjie, Dakuai wenhua, 2008b.

-.. Lianrenban zhongyingcidian (恋人版中英词典) [A Concise Chinese-English Dictionary

for Lovers]. Translated by Miu Ying, Xinxing chubanshe, 2009a.

--. UFO in Her Eyes. Chatto \& Windus, 20ogb. 
-.. Taotieqingchun de ershige shunjian (饕䬸青春的二十个瞬间) [2o Fragments of $a$ Ravenous Youth]. Translated by Miu Ying, Xinxing chubanshe, 2010.

--. "Great Art Behind an Iron Curtain: Are All Chinese Novelists 'State Writers." The Independent, 15 Dec. 2012, www.independent.co.uk/arts-entertainment/books/features/ great-art-behind-an-iron-curtain-are-all-chinese-novelists-state-writers-8412987.html. Accessed 23 Oct. 2020.

--. "Beyond Dissidence." Xiaolu Guo website, 2013, www.guoxiaolu.com/WR_Beyond_ Dissidence.htm. Accessed 23 Oct. 2020.

-.. "Why Do We Still Pretend We Are Free?" Guernica, 30 Jan. 2014. www.guernicamag. com/xiaolu-guo-why-do-we-still-pretend-we-are-free. Accessed 23 Oct. 2020.

--. I Am China. Chatto \& Windus, 2014b.

--. Once Upon a Time in the East: A Story of Growing Up. Chatto \& Windus, 2017.

--. "An Interview with Xiaolu Guo." Apple Podcast, 14 May 2019, podcasts.apple.com/gb/ podcast/an-interview-with-xiaolu-guo/id1366889715?i=1000438071177. Accessed 23 Oct. 2020.

Guo, Wangtaolue. "Rhizomizing the Translation Zone: Xiaolu Guo and A Concise ChineseEnglish Dictionary for Lovers." TranscUlturAl: A Journal of Translation and Cultural Studies, vol. 10, no. 1, 2018, pp. 102-116.

Han Yitong 韩易桐. “Guo Xiaolu: duiyu naxie pai shangyepian de daoyan, wo hen bu xinren (郭小橹: 对于那些拍商业片的导演, 我很不信任) [Xiaolu Guo: I do not trust those directors who do commercial films]" sohu, 14 June 2012, cul.sohu.com/s2012/ diyixianchang57/. Accessed 23 Oct. 2020.

Hassan, Waïl. "Translational Literature and the Pleasures of Exile." PMLA, vol. 131, no. 5, 2012, pp. 1435-1443.

Hwang, Eunju. "Love and Shame: Transcultural Communication and its Failure in Xiaolu Guo's A Concise Chinese-English Dictionary for Lovers." ARIEL, vol. 43, no. 4, 2012, pp. 69-95.

Jaggi, Maya. "We're All Aliens Now." The Guardian, 14 Feb. 2009, www.theguardian.com/ books/2009/feb/14/xiaolu-guo-ufo-in-her-eyes. Accessed 23 Oct. 2020.

Jameson, Frederic. "Third-World Literature in the Era of Multinational Capitalism." Social Text, vol. 15, 1986, pp. 65-88.

Kong, Belinda. "Guo Xiaolu and the Contemporary Chinese Anglophone Novel." Oxford Handbook of Modern Chinese Literatures, edited by Carlos Rojas and Andrea Bachner, Oxford UP, 2016, pp. 474-497.

Larsen, Svend Eric. "World Literature or Literature Around the World?" World Literature, World Culture, edited by Karen-Margrethe Simonsen and Jakob Stougaard-Nielsen, Aarhus UP, 2008, pp. 25-36.

Lee, Gregory, and Noël Dutrait. "Conversations with Gao Xingjian: The First 'Chinese' Winner of the Nobel Prize for Literature." The China Quarterly, no. 167, 2001, pp. 738-748.

Oboe, Annalisa. "Language, Eros and Culture in Xiaolu Guo's A Concise Chinese-English Dictionary for Lovers." The Tapestry of the Creative Word in Anglophone Literatures, edited by Antonella Riem, et al., Forum Edizioni, 2013, pp. 267-279. 
Poon, Angelia. "Becoming a Global Subject: Language and the Body in Xiaolu Guo's $A$ Concise Chinese-English Dictionary for Lovers." Translational Literature, vol. 6, no. 1, 2013, pp. 1-9.

Shi, Flair Donglai. "Post-Mao Chinese Literature as World Literature: Struggling with the Systematic and the Allegorical." Comparative Literature \& World Literature, vol. 1, no. 1, 2016, pp. 20-34.

--. "Translating the Translational: A Comparative Study of the Taiwanese and Mainland Chinese Translations of Xiaolu Guo's A Concise Chinese-English Dictionary for Lovers." Translation and Literature, vol. 30, no. 1, 2021, pp. 1-29.

Shih, Shu-mei. "Global Literature and the Technologies of Recognition." PMLA, vol. 119, no. 1, 2004, pp. 16- 30.

Spyra, Ania. "On Labors of Love and Language Learning: Xiaolu Guo Rewriting the Monolingual Family Romance." Studies in the Novel, vol. 48, no. 4, 2016, pp. 444-461.

Walkowitz, Rebecca L. Born Translated: The Contemporary Novel in an Age of World Literature. Columbia UP, 2015. 